\title{
What shapes our knowledge of the relationship between water deficiency stress and plant volatiles?
}

\author{
Krisztina Szabó ${ }^{1}$ [D $\cdot$ Péter Zubay ${ }^{1}$ Éva Németh-Zámboriné ${ }^{1}$
}

Received: 8 July 2019 / Revised: 23 June 2020 / Accepted: 5 July 2020 / Published online: 11 July 2020

(c) The Author(s) 2020

\begin{abstract}
In this review, we attempt to highlight the issues related to plant volatile and essential oil studies in connection with drought stress. Our literature search included all publications on drought stress related to either the biosynthetic context of volatiles, or the ecophysiology and environmental interactions of species via these compounds. In addition, we surveyed publications on practical questions, such as the optimization of cultivation techniques of essential oil bearing plants. Emphasis was placed on theories explaining regularities in the detected symptoms of test plants and discrepancies of other results. Carbon allocation from primarily metabolism to secondary one, competition of parallel terpenoid pathways and the surplus of reductive power are the main theories that are discussed around. During evaluation, the main question was: which principles have already been justified in the biosynthesis/accumulation/emission of plant volatiles due to drought stress? What are the strengths and limitations of the theories? In discussing results from different scientific fields, the intention is to reveal logical connections that are yet to be addressed in the future co-operative multidisciplinary research. The simple question-whether drought stress increases the biosynthesis/accumulation/emission of plant volatiles-is not adequate any more. According to current scientific knowledge, the fine-tuning of all related variables is the challenge of next generation studies, especially for MAP species.
\end{abstract}

Keywords Drought stress · Volatile isoprenoids · Essential oil · Carbon allocation · Opportunistic emission · Over-reduced state

\section{Introduction}

Stress in plant life is defined as any external factors or deviations from optimal conditions that adversely affect plant homeostasis (Lichtenthaler 1996). Water deficiency stress occurs when the amount of water decreases to a level limiting plant life (growth, reproduction or survival) and impairing plant metabolism (Tardieu 1996; Kulak et al. 2019). A synonym term is the category of drought stress, but sometimes water stress is used in the literature with the same meaning, excluding flooding from the interpretation (Lewitt 1980; Simon et al. 1992; Munné-Bosch and Alegre 1999; Said-Al Ahl et al. 2009; Ahmadian et al. 2011;

Communicated by M. J. Reigosa.

Krisztina Szabó

szabo.krisztina@kertk.szie.hu

1 Department of Medicinal and Aromatic Plants, Faculty of Horticultural Science, Szent István University, Villányi Str. 29-43, Budapest 1118, Hungary
Azhar et al. 2011; Debnath et al. 2011; Chrysargyris et al. 2016; Morshedloo et al. 2017; Kulak et al. 2019). As an experimental implementation, the amount of water inducing water deficiency must be defined by the wilting point (Furr and Reeve 1945; Said-Al Ahl et al. 2009; Asadi et al. 2012). However, several definitions are present in the literature, depending on the aim of the study. Subcategories such as mild, moderate and severe drought stress are frequently found in publications (Llusià and Peñuelas 1998; Bettaieb et al. 2009; Laribi et al. 2009; Nowak et al. 2010; Selmar and Kleinwächter 2013a; Bloem et al. 2014; Yadav et al. 2014, Kleinwächter et al. 2015; Saeedfar et al. 2015; Griesser et al. 2015; Chrysargyris et al. 2016; NémethZámbori et al. 2016; Radácsi et al. 2016; Morshedloo et al. 2017; Caser et al. 2018, 2019). This approach suggests a continuously induced change at cellular level in response to decreased water availability, while the strict definition of wilting point evidently implies a certain point in water availability where stress begins.

Metabolites produced by plants are usually categorized in two main groups. Primary metabolites include all basic, 
constructive, essential molecules of plant life. They are primary products of photosynthesis and basic biosynthetic pathways. A metabolite is considered secondary, when its formation is not strictly indispensable for plant life. Its biosynthesis is based on primary metabolites. Their specificity is often restricted to a certain taxonomic category (Pott et al. 2019).

Among secondary compounds, vascular plants have a wide array of volatile secondary compounds. They have great ecological usefulness in the communication with the surrounding flora and fauna (Rosenkranz and Schnitzler 2016). The term plant volatiles covers chemical compounds produced by plants that can spread in the air at environmental temperature. Plant volatiles are typically grouped into four main sections depending on their biosynthetic origin: terpenes (isoprene, monoterpenes such as linalool or geraniol and sesquiterpenes such as $\beta$-bisabolene or $\beta$-caryophyllene), fatty acid derivatives (short-chain derivatives with different functional groups, furthermore a distinct group of green leaf volatiles (GLVs) released upon mechanical damage), amino acid derivatives (volatile amines, indoles and sulfur compounds) and phenylpropanoid compounds (eugenol, methyleugenol, chavicol, and methyl chavicol) (Dudareva et al. 2004; Rosenkranz and Schnitzler 2016). From the viewpoint of atmospheric pollution, the term biogenic volatile organic compounds (biogenic VOCs) is defined as atmospheric volatile molecules originating from biological sources except carbon dioxide and monoxide (Kesselmeier and Staudt 1999). Biogenic VOCs significantly affect atmospheric chemistry and climate. Their emission is influenced by environmental factors-among them drought—, therefore they have strong relevance in drought related surveys (Bertin and Staudt 1996; Llusià and Peñuelas 1998). While the expression of volatile organic compounds (VOCs) in plant research studies is mainly applied in the context of interaction with the surrounding environment, there is a significant group of plant secondary metabolites-namely the constituents of essential oils-where their volatility is especially utilized by humans (Fig. 1).

Essential oils (EO) are defined as products of extraction after a process such as distillation or, in the case of citrus rinds, the mechanical processing of natural materials (ISO 9235: 2014). The term essential oil can be used properly only in research studies where the content of volatile compounds of a species is measured with methods complying with the ISO standard. The ISO definition of essential oils expresses clearly one main aspect of all publications dealing with essential oil content and composition changes of species as a consequence of drought stress: results can only approximate the in planta situation.

The separated terminology of different scientific fields (VOCs and EO) predetermines the compartmentation of research ideas and thinking. Emission studies show isoprene and monoterpenes as the most prominent compounds within VOCs (Kesselmeier and Staudt 1999; Dudareva et al. 2004; Rosenkranz and Schnitzler 2016). Therefore, the two terms, plant volatiles and essential oils, should be connected somehow when the theoretical background of drought stress reactions of essential oil bearing plants is addressed.

Drought is receiving rising attention in the literature because of the effect of climate change and all its ecological consequences, but it is equally crucial in the optimization
Fig. 1 Overview of subjects related to water deficiency and plant volatiles

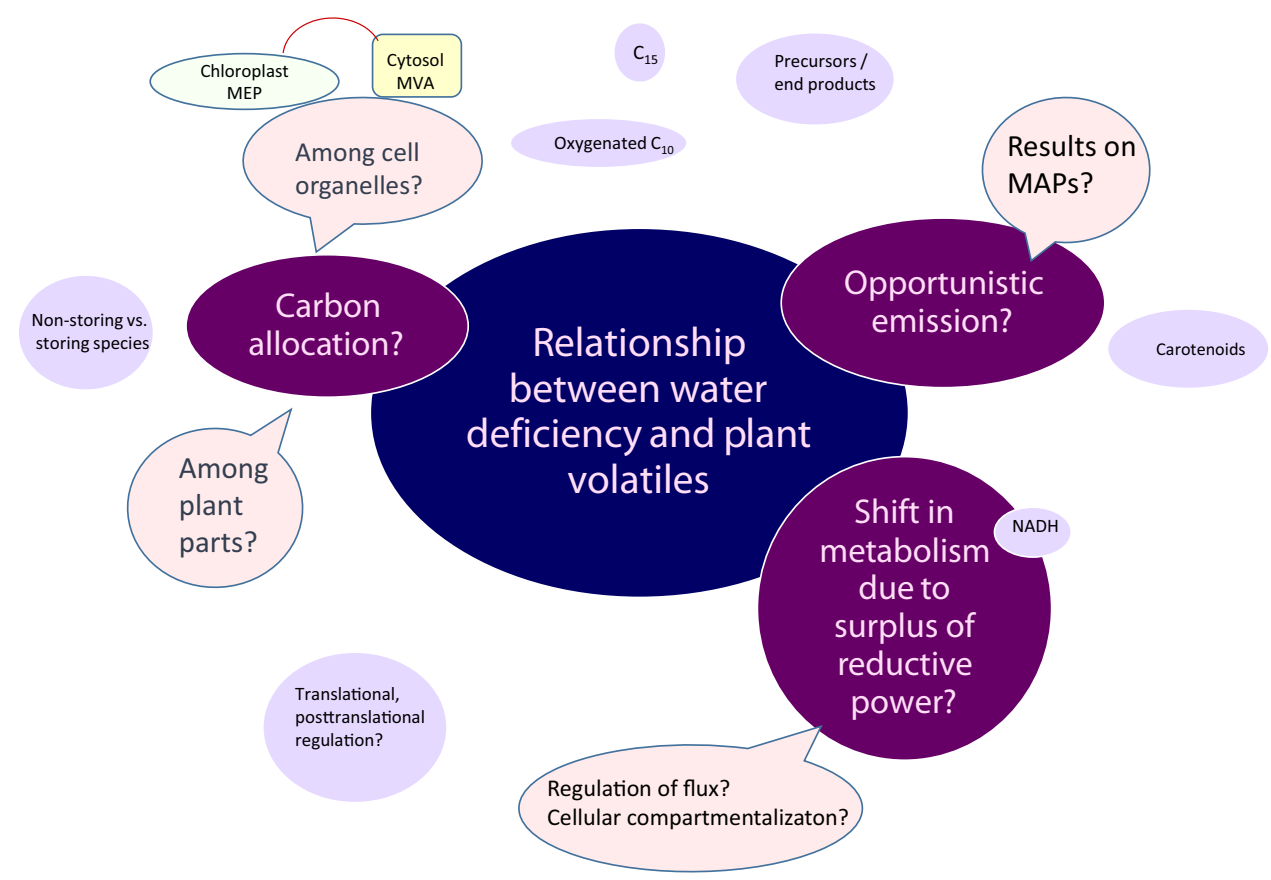


of secondary metabolite production/cultivation techniques of medicinal and aromatic plant (MAP) species. Both in nature and in experimental designs, drought stress highly differs in its timing, length of time and severity; furthermore, test species/genotypes are never the same. This fact results in great variations in consequences that have been detected in experiments, which hinders generalization (Szabó et al. 2017).

Therefore, in the following sections, the research results on plant volatile isoprenoids in drought stress experiments were evaluated in the light of different theories explaining the link between drought stress and production of volatile compounds. Ideas of different researchers are connected in a logical flow to find regularities or identify knowledge gaps for studies of next generations.

\section{The contrast of different theories}

\section{Carbon allocation theory}

Drought stress limits the operation of photosynthetic apparatus in plants as a consequence of stress induced stomata closing. A frequently cited hypothesis (Kreuzwieser et al. 2002; Turtola et al. 2003; Delfine et al. 2005; Šimpraga et al. 2011) is, that the decreased $\mathrm{CO}_{2}$ uptake and fixation somehow is compensated by the altered carbon allocation to maintain/ increase secondary metabolite synthesis for the protection of plants under stress circumstances.

According to Delfine et al. (2005) the water deficit stress increased the monoterpene concentration ( $\mu \mathrm{g} / \mathrm{g} \mathrm{DW})$ by the allocation of carbon to terpenoid biosynthesis rather than by maintaining the biomass production in a drought stress experiment with Rosmarinus officinalis and Mentha spicata.

However, when carbon allocation is suggested, it is not enough to express terpene or EO concentration on a dry weight basis. In these cases namely the question arises: whether the increase of secondary metabolites among stress circumstances is on the basis of a real increase via biosynthesis or just attributable to a change in reference numbers (e.g. smaller biomass production with the same rate of biosynthesis) (Kleinwächter et al. 2015; Paulsen and Selmar 2016). To demonstrate the importance of this aspect, some data extracted from the literature are presented in Table 1. In this table, the changing ratio of EO production expresses the relative decrease of carbon use for primary and secondary metabolisms compared to the control conditions as benchmark $(100 \%)$. It shows also the difference in conclusions when either the theoretical background or the practical questions of drug quality/quantity changes are in focus.

The examples presented in Table 1 show the different situations. Increased accumulation, but without significant decrease of biomass can be read in the publication of Ahmadian et al. (2011). They recorded slightly less seed and biological yield/biomass ( $\mathrm{kg} / \mathrm{ha}$ ) for Cuminum cyminum, while the EO contents (\%) were significantly higher at reduced watering. As it is shown, the biomass and seed yield resulted in 80 and $86 \%$ of the control data, but the essential oil yield is $93 \%$ when compared with the control, therefore the increase in EO \% may be a drought stress related genuine increase of secondary metabolism. Carbon allocation allowed a lower level of decrease in secondary metabolism compared to the primary metabolism used for plant dry matter production (Table 1).

In a similar example, Khalid et al. (2006) demonstrated a significant and parallel elevation of EO content of $\mathrm{Oci}$ mum basilicum due to drought stress. However, the yield of the EO (ml/plant) decreased in consequence of the severely reduced biomass production. When the rate of decrease in biomass versus the rate of decrease in EO yield are compared, a drought stress connected genuine increase of EO production is detected contrary to the unsatisfactory result for the practical aspects of cultivation (e.g. lower drug and EO yields). As for the aspect of drug quality enhancement, the increase in EO content due to water deficiency stress presents an advantageous potential (Table 1).

The next example is about Dracocephalum moldavica (Said-Al Ahl and Abdou 2009). Due to water deficiency, both the biomass (fresh mass g/plant) and EO (\% and $\mathrm{ml} /$ plant) decreased. Following the same calculation, we can recognize that in this experiment no carbon allocation can be interpreted from the data. The biomass of the plants in the water deficiency treatment reached $77 \%$, while the essential oil yield ( $\mathrm{ml} /$ plant) reached only $60 \%$ of that of the control plants (Table 1).

Lower soil water content (40\% SWC in contrast to the control 70\% SWC) resulted in both significantly lower biomass production and EO content in the case of four Lamiaceae species: lemon balm, thyme, peppermint and marjoram (Németh-Zámbori et al. 2016). Similarly to the former trial, percentage data of changes in biomass and EO yield for all species prove, that presumably no carbon allocation was present in the species under drought stress, since the rate of decrease in EO yield (ml/plant) is bigger than the relative decrease in biomass production (Table 1).

Most papers do not mention the relative decrease of EO/ plant versus biomass for the different treatments. However, following the calculation of Paulsen and Selmar (2016) as an example, one can easily calculate if the values of EO content under drought stress represent a genuine increase or even a decrease in biosynthesis. Based on this analysis it can be concluded that the carbon allocation in the examples discussed is not always present, therefore generalization of the carbon allocation theory cannot be supported.

There are limited references where carbon allocation have been directly quantified, just as it was made for Fagus sylvatica young trees under drought stress (Šimpraga et al. 2011). 
Table 1 Examples for calculation of the rate of biosynthesis in relation to the biomass as reference value, based on Paulsen and Selmar (2016) and further extracted data from references

\begin{tabular}{|c|c|c|c|c|c|c|}
\hline \multirow[t]{2}{*}{ Reference } & \multirow[t]{2}{*}{ Species } & \multirow[t]{2}{*}{ Parameters } & \multicolumn{4}{|c|}{ Results of treatments and ratios to each other } \\
\hline & & & Control & In $\%$ & Stress treatment & In $\%$ \\
\hline \multirow[t]{3}{*}{ Paulsen and Selmar (2016) } & \multirow[t]{3}{*}{ Thymus vulgaris } & Biomass & $17.45 \mathrm{~g} /$ plant & 100 & $11.63 \mathrm{~g} / \mathrm{plant}$ & 67 \\
\hline & & Concentration of terpenes & $6.42 \mathrm{mg} / \mathrm{g} \mathrm{DW}$ & 100 & $7.44 \mathrm{mg} / \mathrm{g} \mathrm{DW}$ & 116 \\
\hline & & Total amount of terpenes & $112 \mathrm{mg} /$ plant & 100 & $87 \mathrm{mg} /$ plant & 78 \\
\hline \multirow[t]{2}{*}{ Reference } & \multirow[t]{2}{*}{ Species } & \multirow[t]{2}{*}{ Parameters } & \multicolumn{4}{|c|}{ Results of treatments and ratios to each other } \\
\hline & & & 3 irrigations & In $\%$ & 2 irrigations & In $\%$ \\
\hline \multirow[t]{4}{*}{ Ahmadian et al. (2011) } & \multirow[t]{4}{*}{ Cuminum сутіпит } & Biological yield & $775 \mathrm{~kg} / \mathrm{ha}$ & 100 & $624 \mathrm{~kg} / \mathrm{ha}$ & 80 \\
\hline & & Seed yield & $402 \mathrm{~kg} / \mathrm{ha}$ & 100 & $349 \mathrm{~kg} / \mathrm{ha}$ & 86 \\
\hline & & EO content & $2.6 \%$ & 100 & $2.8 \%$ & 107 \\
\hline & & EO yield & $10,452 \mathrm{ml} / \mathrm{ha}$ & 100 & $9772 \mathrm{ml} / \mathrm{ha}$ & 93 \\
\hline \multirow[t]{2}{*}{ Reference } & \multirow[t]{2}{*}{ Species } & \multirow[t]{2}{*}{ Parameters } & \multicolumn{4}{|c|}{ Results of treatments and ratios to each other } \\
\hline & & & $\begin{array}{l}75 \% \text { Field water } \\
\text { capacity (FWC) }\end{array}$ & In $\%$ & $50 \% \mathrm{FWC}$ & In $\%$ \\
\hline \multirow[t]{4}{*}{ Khalid (2006) } & \multirow[t]{4}{*}{ Ocimum basilicum } & Fresh yield & $2773 \mathrm{~g} /$ plant & 100 & $1393 \mathrm{~g} /$ plant & 50 \\
\hline & & Dry yield & $554 \mathrm{~g} /$ plant & 100 & $279 \mathrm{~g} /$ plant & 50 \\
\hline & & EO content & $0.33 \%$ & 100 & $0.38 \%$ & 115 \\
\hline & & EO yield & $1.83 \mathrm{~g} /$ plant & 100 & $1.10 \mathrm{~g} /$ plant & 60 \\
\hline \multirow[t]{2}{*}{ Reference } & \multirow[t]{2}{*}{ Species } & \multirow[t]{2}{*}{ Parameters } & \multicolumn{4}{|c|}{ Results of treatments and ratios to each other } \\
\hline & & & $\begin{array}{l}80 \% \text { Soil water } \\
\text { capacity (SWC) }\end{array}$ & In $\%$ & $40 \%$ SWC & In $\%$ \\
\hline \multirow{3}{*}{$\begin{array}{l}\text { Said-Al Ahl and Abdou } \\
\text { (2009) }\end{array}$} & \multirow[t]{3}{*}{ Dracocephalum moldavica } & Fresh mass & $36 \mathrm{~g} /$ plant & 100 & $28 \mathrm{~g} /$ plant & 77 \\
\hline & & EO content & $6.2 \%$ & 100 & $5.2 \%$ & 83 \\
\hline & & EO yield & $23 \mathrm{ml} /$ plant & 100 & $14 \mathrm{ml} /$ plant & 60 \\
\hline \multirow[t]{2}{*}{ Reference } & \multirow[t]{2}{*}{ Species } & \multirow[t]{2}{*}{ Parameters } & \multicolumn{4}{|c|}{ Results of treatments and ratios to each other } \\
\hline & & & $70 \%$ SWC & In $\%$ & $40 \%$ SWC & In $\%$ \\
\hline Németh-Zámbori et al. & Majorana hortensis & Fresh biomass & $41 \mathrm{~g} /$ plant & 100 & $21.3 \mathrm{~g} / \mathrm{plant}$ & 52 \\
\hline (2016) & & EO content & $2.134 \mathrm{ml} / 100 \mathrm{~g} \mathrm{DW}$ & 100 & $1.755 \mathrm{ml} / 100 \mathrm{~g} \mathrm{DW}$ & 82 \\
\hline & & EO yield & $0.87 \mathrm{ml} /$ plant & 100 & $0.37 \mathrm{ml} /$ plant & 42 \\
\hline & Mentha piperita & Fresh biomass & $52.6 \mathrm{~g} /$ plant & 100 & $11.3 \mathrm{~g} /$ plant & 21 \\
\hline & & EO content & $3.166 \mathrm{ml} / 100 \mathrm{~g} \mathrm{DW}$ & 100 & $2.685 \mathrm{ml} / 100 \mathrm{~g} \mathrm{DW}$ & 85 \\
\hline & & EO yield & $1.66 \mathrm{ml} /$ plant & 100 & $0.30 \mathrm{ml} /$ plant & 18 \\
\hline & Thymus vulgaris & Fresh biomass & $40.4 \mathrm{~g} /$ plant & 100 & $12.0 \mathrm{~g} /$ plant & 30 \\
\hline & & EO content & $4.758 \mathrm{ml} / 100 \mathrm{~g} \mathrm{DW}$ & 100 & $4.223 \mathrm{ml} / 100 \mathrm{~g} \mathrm{DW}$ & 89 \\
\hline & & EO yield & $1.92 \mathrm{ml} /$ plant & 100 & $0.50 \mathrm{ml} /$ plant & 26 \\
\hline & Melissa officinalis & Fresh biomass & $236.8 \mathrm{~g} / \mathrm{plant}$ & 100 & $58.0 \mathrm{~g} /$ plant & 24 \\
\hline & & EO content & $0.298 \mathrm{ml} / 100 \mathrm{~g} \mathrm{DW}$ & 100 & $0.107 \mathrm{ml} / 100 \mathrm{~g} \mathrm{DW}$ & 36 \\
\hline & & EO yield & $0.70 \mathrm{ml} /$ plant & 100 & $0.06 \mathrm{ml} /$ plant & 9 \\
\hline
\end{tabular}

Woody, non-storing, VOC emitting species are suitable subjects to follow the consequences of drought stress, since they react to water deficit with differences in radial stem growth rather than just wilting. If the production of volatiles can be followed simultaneously with registering growth parameters for a longer period by measuring emission in a closed system without cutting and distilling the plant material, then the dynamics of both parameters allow us to study the consequences of drought on isoprene/VOC emission. In this experiment, authors continuously evaluated the status of water deficiency stress in a young $F$. sylvatica via changes in radial stem growth together with simultaneous assessment 
of biogenic VOC emissions and extend of photosynthetic activity. It was confirmed that depending on the severity of drought stress beech shifts its carbon allocation to VOC production or radial stem growth. Increase in monoterpene emission was detected parallel to drought stress until the stem growth was reduced (mild stress). Emission started to drop from the phase the beech stem ceased growing (severe stress). Beyond recording the pattern in monoterpene volatile emission, the authors disclosed an abrupt outbreak in emission of a volatile compound when drought stress was acute and the trees showed pronounced negative stem growth. A similar outcome for the same species was published by another group, too (Wu et al. 2015).

Due to species' specificities the knowledge gained above cannot be transferred to non-woody, volatile-storing species. However, these experiments seem to demonstrate a continuously induced change as response to decreased water availability rather than a certain point in water availability when stress reaction begins, therefore validity of carbon allocation theory could be restricted to a certain period in the homeostatic processes.

A slightly different interpretation of carbon redistribution can be seen in the publication of Turtola et al. (2003). According to the authors, the increase of monoterpenes concentration $(\mu \mathrm{g} / \mathrm{g}$ DW) in woods of Pinus sylvestris and Picea abies seedlings is a result of the reduced plant growth from water deficiency stress, so the carbon built in during the photosynthesis can be employed for the synthesis of monoterpenes. This approach must assume that the reduced plant growth does not mean proportionally reduced photosynthetic activity and/or proportionally reduced chlorophyll content. This logic could be derived mainly from the characteristics of these woody species, where reduced plant growth primarily means less stem thickening. However, the generation of reactive oxygen species due to stress is likely to cause chlorophyll destruction (Foyer et al. 1994). The few papers dealing with this aspect provide contradictory results.

The chlorophyll content (SPAD index values) increased significantly while the biomass decreased due to water deficiency in Satureja hortensis (Radácsi et al. 2016) and in Melissa officinalis (Németh-Zámbori et al. 2017, Zámboriné et al. 2017). However, the presumed higher photosynthetic rate could not be manifested in the consequent increase of the EO content in either case. In Greek sage (Salvia fruti$\cos a$ ), drought stress induced a severely reduced biomass production in parallel with a significant increase of EO percentage, however, total chlorophyll content (mg/g FW) showed fluctuations (Chrysargyris et al. 2016). This latter study also calls attention to the fact that there might be differences among species. In the same experiment, lavender (Lavandula angustifolia) did not show any changes in the parameters which were measured (Chrysargyris et al. 2016). According to Shairat et al. (2018) $40 \%$ reduction in total leaf chlorophyll content (mg/g FW) was identified in drought stressed Satureja rechingeri compared to the control plants. At the same time, the production of several phenolic and monoterpene compounds increased within the 12-day drought stress treatment, indicating that secondary metabolism of this species was improved-either by carbon allocation or the decrease of chlorophyll content rate was not proportional to the loss of fresh biomass.

\section{Carbon allocation approached from the viewpoint of plant anatomy}

Confirming or disproving carbon allocation, investigations may include the context of plant anatomy (e.g. carbon allocation between plant parts or between different tissues, possibility of accumulation of the secreted VOCs in different secretory structures, etc.). Searching among the publications, one can also find examples evaluating the carbon allocation theory based on this approach.

The possibility of the carbon allocation theory is supported (albeit indirectly) by the results of Asensio et al. (2012). In this experiment, the symbiotic arbuscular mycorrhiza colonization increased the demand for carbon in the roots of tomato, inhibiting carbon allocation to non-essential isoprenoids. This resulted in the decrease of root volatile terpenes compared to non-mycorrhizal plants. This study underlines that volatile accumulation/emission of different plant organs may react differently; therefore, validity of the carbon allocation theory could be restricted by physical distance between the sites of carbon demand and terpene synthesis within an individual.

Studies of isoprene and monoterpene-emitting Quercus ilex tree species in pot experiments proved that volatile terpenoid emission is inhibited under progressing/severe drought (Staudt and Seufert 1995; Loreto et al. 1996; Llusià and Peñuelas 1998; Wu et al. 2015). Some authors explain their deduction exactly because of this species does not store isoprenoids (Staudt and Seufert 1995; Loreto et al. 1996). According to the accumulated knowledge on this species, terpenes emitted by $Q$. ilex leaves are not raised from a storage supply, but are synthesized just before emission from currently fixed carbon. Therefore this proves that the emission is directly regulated by the presence of photosynthesis intermediates (Staudt and Seufert 1995; Loreto et al. 1996). As emission is directly inhibited by water deficiency, it can be concluded that the volatile terpene syntheses are not modified by carbon allocation to maintain or even enhance terpene synthesis. Change in monoterpene emission in this species is a response to a shortage of water.

The possibility of carbon allocation between tissues was studied by Kreuzwieser et al. (2002), who found that under conditions of limited photosynthesis the role of xylem-transported carbohydrates may also become 
important for biosynthesis of secondary compounds via carbon allocation. The results of $Q$. robur demonstrated that xylem-transported glucose or its related carbohydrates are further possible carbon sources for leaf isoprene synthesis. At the same time, the authors emphasize that their results were gained on cut twigs, and the experimental results must be affirmed in in vivo plants to prove unequivocally the carbon allocation from xylem to terpene biosynthesis.

Since the aim of this review is to recount the connections among the different ideas, attention must be drawn to the following gap. As far as we know, only sporadic data are available on the possibility, magnitude and importance of in vivo terpene emission parallel to essential oil accumulation of essential oil bearing plants (Dement et al. 1975; Kesselmeier and Staudt 1999). Terpene emission in this case would influence the equation when genuine synthesis is examined. Generally, sampling and collecting of VOCs are carried out in a short timeframe via the headspace technique (Tholl et al. 2006), while drought stress experiments extend to days, weeks or even months. To the best of our knowledge, only a few publications on MAP species (Helicrysum petiolare, Salvia sinaloensis, Salvia dolomica) deal with EO accumulation and VOCs emission within the same experimental design, although biogenic VOCs were sampled only once, while the stress treatments were sustained for a total of 34 days (Caser et al. 2016, 2018, 2019).

Emission and/or evaporation of accumulated and stored volatiles from the plant tissue largely depends on the accumulation structure. In species where EO is accumulating in glandular hairs, recent research indicates the presence of mechanisms providing transport of VOCs to the subcuticular space but restraining their subsequent outward emission. The cuticle and cell wall covering the subcuticular space in glandular hairs seem to be the key to withhold volatiles, although their precise structure and the relevant molecular mechanism are mostly unexplored (Tissier et al. 2017). These glandular hairs are not uniform either, but two main types have been detected in plants, which differ in their potential to withhold the secreted and accumulated volatile molecules (Werker 1993).

Considering the co-occurrence of terpene emission and the accumulation of EO in inner ducts, the example of the Eucalyptus species is the most prominent one. While these trees increase isoprene emission rates during drought, the reaction follows a species-specific threshold for drought tolerance. Accumulation of the EO in these trees shows variable responses to reduced water availability depending on the experimental design and the species used as a test plant in the studies (McKiernan et al. 2014, Dani et al. 2015).

\section{Carbon allocation within the cell}

The hypothesis of carbon allocation requires further considerations and studies about how the allocation takes place within the cell.

Rodríguez-Calcerrada et al. (2013) proved that the increased concentration of soluble sugars in the cytosol due to the applied drought stress, played little role in sustaining isoprene synthesis and emission of Quercus pubescens. This result suggests that in this species there is no import of cytosolic carbon (sugars) into chloroplasts (2-C-methyl-D-erythritol 4-phosphate (MEP) pathway-biosynthesis of isoprenes in $Q$. pubescens, based on the authors' explanation) under severe water deficiency. It also implies the importance of co-occurrence of biosynthetic pathways within the same cell organelle to enable carbon allocation between biosynthetic pathways, mentioned by Dani et al. (2015).

However, in plants, a terpenoid biosynthetic pathway can be found both in cytosol [Mevalonate pathway (MVA)], and chloroplast (MEP) (Lichtenthaler 1999) and terpenoids (including isoprene) as VOCs can be produced by both, depending on the species. Until now, the mechanism of an eventual natural crosstalk (metabolic flow) between the two pathways in case of shortage of precursors [isopenthenyl diphosphate (IPP), dimetylallyl diphosphate (DMAPP)] in planta still remains to be fully unravelled. At the same time the increasing number of in vitro outcomes is pointing towards the possibility of such a metabolic flow of precursors to some degree (McCaskill and Croteau 1995; Dudareva et al. 2005; Bartram et al. 2006; Vranová et al. 2013).

While reflecting on these ideas, the role of both pathways in the synthesis of volatile compounds should be considered. It is generally accepted, that sesquiterpenoids are synthesized via the MVA pathway, while isoprene, hemiand monoterpenoids are the products of the MEP pathway (Vranová et al. 2013). Therefore, in those experiments on MAP species where water deficiency increased the concentration of sesquiterpenes in the EO, the carbon allocation theory within the same cell organelle seems to be verified, however indirectly. The quality changes within the EO could possibly originate in carbon surplus-reuse within the cytosol.

There are several reports indicating similar changes. The amount (absolute/relative) of sesquiterpenes increased in the EO of Carum carvi ( $\mu \mathrm{g} / \mathrm{g}$ DW, Laribi et al. 2009), Salvia officinalis ( $\mu \mathrm{g} / \mathrm{g}$ DW, Bettaieb et al. 2009), L. angustifolia (\%, Chrysargyris et al. 2016), Mentha piperita (\%, Charles et al. 1990), Artemisia апnиa (\%, Yadav et al. 2014) under water deficit, while for Ocimum basilicum the amount of total sesquiterpenes in the EO ( $\mu \mathrm{l} / \mathrm{g}$ DW) decreased (Simon et al. 1992). In many reports other characteristic tendencies could be registered. In $S$. sinaloensis the accumulation of oxygenated monoterpenes (\%) (Caser et al. 2018), and in 
Salvia dolomitica and Helichrysum petiolare the accumulation of oxygenated sesquiterpenes was induced by drought stress (Caser et al. 2016, 2019). In the case of Origanum vulgare, the relative percentage of total oxygenated compounds decreased due to increasing water deficiency (SaidAl Ahl et al. 2009). In the chemotaxonomic evaluation of Hungarian $O$. vulgare subsp. vulgare populations a clear shift towards the oxidized molecules was detected: the ratio of $\beta$-caryophyllene oxide increased significantly due to the unseasonably dry summer (Cserháti et al. 2013). Both in thyme and marjoram, water shortage seemed to increase the synthesis of end products (thymol, carvacrol, sabinenes, linalool) at the expense of their precursors in the same pathway (Németh-Zámbori et al. 2016; Hussein et al. 2019). According to Mohasseli and Sadeghi (2019) this is true only in the case of mild (60\% field capacity) water deficiency stress for two thyme species (Thymus serphyllum and Thymus vulgaris).

\section{Opportunistic emission of volatile isoprenoids theory}

Terpenoid biosynthesis includes not only the volatile hemi-, mono- and sesquiterpenoids, but also isoprenoids with higher carbon atom numbers synthesized from the same five-carbon-atom units. Somewhat similar to the carbon allocation theory or even as a side aspect, a competition between isoprenoid compounds under water shortage conditions might be presumed. The hypothesis of opportunistic emissions of volatile isoprenoids emphasizes the terms of essential versus non-essential isoprenoids. According to Owen and Peñuelas (2005) VOCs are not essential in all plants, although in certain species their emission provides eco-physiological advantages and therefore has been evolved and maintained through the evolution. The opportunistic hypothesis suggests that circumstances modifying the synthesis of higher isoprenoids (abscisic acid, gibberellic acids, tocopherol, sterols and carotenoids) are responsible indirectly for the amount of non-essential isoprenoids. Their synthesis may be primarily depending on the remaining surplus precursors (IPP and DMAPP).

Nevertheless, contradicting results have been published on this issue as well. An example of this is A. annua, which resulted in decrease of total carotenoid content (mg/g FW) as a higher isoprenoid, while the ratio (\%) of sesquiterpenoids increased parallel to the upregulation of sesquiterpene cyclase enzyme $(S Q C)$ under mild or moderate water stress treatments (Yadav et al. 2014). Additionally, carotenoids (mg/g FW) in S. sinaloensis and S. dolomitica were not affected by different water regimes (Caser et al. 2018, 2019), while the biogenic VOC and EO profiles altered. Severe water deficiency dramatically reduced the carotenoid content (mg/g FW) of $H$. petiolare, and the amount of VOC and EO was not affected, although both spectra were modified. Finally, a completely different tendency was measured in $O$. vulgare. The carotenoid content $(\mathrm{mg} / \mathrm{g} \mathrm{FW})$ increased with increasing water deficiency level and the EO content (\%) decreased significantly when severe water deficit was maintained (Khalil and El-Noemani 2015).

The difference among species in this context suggests that the validity of this theory might be restricted to certain plant taxa.

\section{The question of the phenylpropanoid pathway}

In numerous species, essential oil compounds include also volatile phenylpropanoid molecules (Iijima et al. 2004; Mandoulakani et al. 2017). Various papers indicate that enhanced accumulation of polyphenols (anthocyanin, flavonoid, etc.) may be a stress response resulting from initiation of the phenoloid pathway by the (drought) stress effects (e.g. ChalkerScott 1999; Alishah et al. 2006; Yuhang et al. 2011; Yuan et al. 2012; Nakabayashi et al. 2014; Griesser et al. 2015; Shairat et al. 2018). According to the findings of NémethZámbori et al. (2017) on four EO accumulating species, it was concluded that in some of them the parallel decrease of biomass and elevation of the content of total phenolic content might allow the latter to function as an adequate marker in predicting the lack of appropriate water supply.

Interestingly, only a few attention has been given to the volatile phenoloids in studying drought stress responses of EO accumulating species. As they are products of a pathway basically different to the one of the isoprenoids, they could represent new pros and cons in ascertaining the theories we have discussed.

Scientists believe that with increasing understanding of these pathways it will be possible to select genotypes with better adaptation characteristics (Wang et al. 2003, Witcombe et al. 2016). Indeed, genotype dependence and its manifestation in secondary metabolism is another emerging issue in drought tolerance. Results about genotype dependent drought reaction were published in the case of Melissa officinalis (Szabó et al. 2017) and Petroselinum crispum (Petropoulos et al. 2008) cultivars, in two closely related species as Thymus vulgaris and Thymus serpyllum (Moradi et al. 2017) and for two subspecies of $O$. vulgare (subsp. virens and subsp. gracile) (Morshedloo et al. 2017).

\section{The surplus of reductive power theory}

Another hypothesis behind the elevated level of secondary metabolites in case of stress reactions is the surplus of reductive power theory (Selmar and Kleinwächter 2013a, b; Kleinwächter and Selmar 2015). According to this idea, the notable decrease of available $\mathrm{CO}_{2}$ due to drought finally eventuates in oxidative stress with an oversupply of 
reduction equivalents. To cope with the excess NADH plants shift their metabolism towards reactions employing reducing agents, such as the synthesis of isoprenoids, phenols and alkaloids, even without altering the relevant enzyme activity. This theory is supported by further data on the decline of over-reduced status and accumulation of monoterpene compounds in consequence of elevated $\mathrm{CO}_{2}$ concentration (Nowak et al. 2010).

However, the same logical questions arise here as well; namely, how the relocation of NADH is taking place within the cell to reach all the different biosynthetic pathways in different organelles; how the regulation of flux is involved; and are there any limiting obstacles in intracellular transport? This is especially interesting, since cellular compartmentalization in plant metabolism is highly complex (Heinig et al. 2013), which certainly brings to light the export of excess NADH to different secondary metabolic pathways in different organelles. So far, mitochondria seem to play a major role in ensuring the removal of excess redox equivalents from chloroplasts under both limiting and optimal conditions (Raghavendra and Padmasree 2003). Studies in different bacteria indicate the role of secondary metabolism to maintain cellular homeostasis by regenerating intracellular $\mathrm{NAD}^{+}$concentrations (Price-Whelan et al. 2007; Dietrich et al. 2008); however, the direct assessment of secondary metabolites for MAPs in these processes has yet to be carried out.

\section{Molecular tools in support of discoveries}

Following gene expressions under different water supplies can certainly provide clues to whether the increase in any terpenoid biosynthesis is only an exhaustion of stress-related surplus reducing agents, or an active biosynthetic change due to upregulation of certain genes involved in terpenoid synthesis. However, it is difficult to capture the right time for sampling, since the phenotypical response is generally delayed compared to the gene expression level; this is due to post-transcriptional regulation, protein synthesis and terpenoid production. This approach was followed in MAPs by Caser et al. (2019) in S. dolomitica, by Morshedloo et al. (2017) in O. vulgare, by Shairat et al. (2018) in S. rechingeri and by Yadav et al. (2014) in A. аппиа. In all of these cases, the up- or down-regulation of key genes detected was positively related to changes in the EO of corresponding species indicating a transcriptional regulation of the synthesis.

A completely new level of analysis in gene expression can be seen in the publication of Zhang et al. (2019), where the gene expressions of Populus deltoides were followed under water deficiency stress conditions. The global transcriptome survey of the RNA-sequence data could facilitate tracking of all expression patterns of genes engaged in both terpenoid pathways (MVA and MEP/DOXP), giving a complex insight which requires equally high investment from the technical and financial points of view. These possibilities are not readily available for most of the scientists involved in drought response studies.

It is now commonly agreed, that MVA and MEP pathways are regulated at both transcript and protein levels to control precursor supply (Vranová et al. 2013). In general, less information is available on the changes in the biosynthesis rate due to translational and posttranslational regulations of MVA and MEP/DOXP pathway enzymes. Differences in expression or accumulation level of isozymes in plants regulated by environmental events is now emerging. Future trend in research will presumably focus on these questions, too.

\section{Conclusion and outlook}

Plant taxa exhibit significant differences; therefore, evaluation of their reactions to drought is even much more challenging. For the most part, drought stress experiments have been focusing on selected partial questions, which inevitably are reflected in both the methods used and throughout the interpretation of data.

Considering the principal outcome of this review, we can conclude that the simple question-whether drought stress increases the biosynthesis/accumulation/emission of plant volatiles-is not adequate any more. Generalization to such an extent distorts reality. According to current scientific knowledge, the fine-tuning of all related variables is the challenge of next generation studies, especially for MAP species.

According to the available references one of the basic uncertainties may derive from improper definition of drought. Definition of water supply levels (e.g. mild, moderate, severe) for water deficiency stress studies should reflect the ecological requirements of test species instead of mechanically copy the experimental design of earlier publications on other species. Optimum water demand is rarely given as SWC \%/FWC \% or wilting point in botanical-coenological descriptions or in cultivation guidelines, therefore translation of this knowledge into water supply setting is essential. It only makes sense to follow any indicator of drought stress if this very first step is defined properly. Definitions of mild, moderate or severe drought stress should reflect changes in plant physiological data (from water potential changes to membrane damage). Publications of MAP species dealing with drought stress rarely explain the correlation of different water supply settings with the water demand of test species.

Limits of all kind of studies must be understood when outcomes are listed. Theoretical background explanations (not proved but assumed) should not be expected and included in studies with practical aim and experimental design such as the case in drug quality optimization. Applying rules of population 
genetics when dealing with sampling is crucial. Molecular biological studies rarely could cover the representative number of individuals in an accession to examine properly the reaction of a population/variety to water deficiency. Furthermore, mass sampling of several individuals due to limited sample size is implausible. The small sample size usually taken for molecular studies could further limit the portrayal of an individual, because it cannot represent the necessary plant organs for volatile (essential oil) accumulation measurement within the same experiment.

Focusing primarily on MAP species, the following issues were outlined by this joint assessment of publications. In the future, measurement of both emission and accumulation of volatiles for the whole period of water deficiency stress could result in deeper understanding of drought reactions. Next generation research must focus on the interrelation of different coping mechanisms (shift in secondary metabolism and/or initiation of other carbon sources as a substitute for photosynthesis), their correlation to timing, duration and severity of drought stress; their dependency on species specificities, plant anatomical constitution and aspects of secondary metabolite pathway.

Probably a degree of drought stress exists in which a desired essential oil accumulation or even an altered essential oil composition is achievable. Trials on endless variations of factors in a complex net of interactions (species/genotype/water deficit treatments/other stress and environmental effects) will always have a limited applicability without deep understanding how the different water supply affects volatile production. Therefore, more research is required to reveal the molecular and biochemical mechanisms that allow for fine-tuning in cultivation. It would be necessary, that co-operative multidisciplinary studies with an omics approach should be given high priority to change the perspective of discoveries in drought stress experiments.

Author contribution statement KS reviewed the literature and wrote the article. PZ took part in literature search and general brainstorming on the subject. ÉNZ discussed the manuscript with K Szabó with several good suggestions, additional parts and corrections.

\footnotetext{
Acknowledgements Open access funding provided by Szent István University. This research was supported by the Ministry for Innovation and Technology within the HE Institutional Excellence Program (NKFIH-1159-6/2019), by OTKA Scientific Foundation (No. NN108633) and the EU-Erasmus + EOHUB project (600873-EPP-1-2018-1ES-EPPKA2-KA).
}

Open Access This article is licensed under a Creative Commons Attribution 4.0 International License, which permits use, sharing, adaptation, distribution and reproduction in any medium or format, as long as you give appropriate credit to the original author(s) and the source, provide a link to the Creative Commons licence, and indicate if changes were made. The images or other third party material in this article are included in the article's Creative Commons licence, unless indicated otherwise in a credit line to the material. If material is not included in the article's Creative Commons licence and your intended use is not permitted by statutory regulation or exceeds the permitted use, you will need to obtain permission directly from the copyright holder. To view a copy of this licence, visit http://creativecommons.org/licenses/by/4.0/.

\section{References}

Ahmadian A, Tavassoli A, Amiri E (2011) The interaction effect of water stress and manure on yield component, essential oil and chemical composition of cumin (Cuminum cyminum). Afr J Agric Res 6(10):2309-2315

Alishah HM, Heidari R, Hassani A, Dizaji AA (2006) Effect of water stress on some morphological and biochemical characteristics of purple basil (Ocimum basilicum). J Biol Sci 6(4):763-767

Asadi S, Lebaschy MH, Khourgami A, Rad AHS (2012) Effect of drought stress on the morphology of three Salvia sclarea populations. Ann Biol Res 3(9):4503-4507

Asensio D, Rapparini F, Peñuelas J (2012) AM fungi root colonization increases the production of essential isoprenoids vs. nonessential isoprenoids especially under drought stress conditions or after jasmonic acid application. Phytochemistry 77:149-161

Azhar N, Hussain B, Ashraf MY, Abbasi KY (2011) Water stress mediated changes in growth, physiology and secondary metabolites of desi ajwain (Trachyspermum ammi L.). Pak J Bot 43:15-19

Bartram S, Jux A, Gerd Gleixner G, Boland W (2006) Dynamic pathway allocation in early terpenoid biosynthesis of stress-induced lima bean leaves. Phytochemistry 67:1661-1672

Bertin N, Staudt M (1996) Effect of water stress on monoterpene emissions from young potted holm oak (Quercus ilex L.) trees. Oecologica 107:456-462

Bettaieb I, Zakhama N, Wannes WA, Kchouk ME, Marzouk B (2009) Water deficit effects on Salvia officinalis fatty acids and essential oil composition. Sci Hortic 120:271-275

Bloem E, Haneklaus S, Kleinwächter M, Paulsen J, EwaldSchnug E, Selmar D (2014) Stress-induced changes of bioactive compounds in Tropaeolum majus L. Ind Crops Prod 60:349-359

Caser M, D’Angiolillo F, Chitarra W, Lovisolo C, Ruffoni B, Pistelli L, Pistelli L, Scariot V (2016) Water deficit regimes trigger changes in valuable physiological and phytochemical parameters in Helichrysium petiolare Hilliard \& B.L: Burtt. Ind Crops Prod 83:680-692

Caser M, D'Angiolillo F, Chitarra W, Lovisolo C, Ruffoni B, Pistelli L, Pistelli L, Scariot V (2018) Ecophysiological and phytochemical responses of Salvia sinaloensis Fern. to drought stress. Plant Growth Regul 84(2):383-394

Caser M, Chitarra W, D'Angiolillo F, Perrone I, Demasi S, Lovisolo C, Pistelli L, Pistelli L, Scariot V (2019) Drought stress adaptation modulates plant secondary metabolite production in Salvia dolomitica Codd. Ind Crops Prod 129:85-96. https://doi. org/10.1016/j.indcrop.2018.11.068

Chalker-Scott L (1999) Environmental significance of anthocyanins in plant stress responses. Photochem Photobiol 70(1):1-9. https ://doi.org/10.1111/j.1751-1097.1999.tb01944.x

Charles DJ, Joly RJ, Simon JE (1990) Effects of osmotic stress on the essential oil content and composition of peppermint. Phytochemistry 29(9):2837-2840

Chrysargyris A, Laoutari S, Litskas VD, Stavrinides MC, Tzortzakis N (2016) Effects of water stress on lavender and sage biomass production, essential oil composition and biocidal properties against Tetranychus urticae (Koch). Sci Hortic 213:96-103

Cserháti B, Sárosi Sz, Rajhárt P, Németh ZÉ, Szabó K (2013) Biological variability of Hungarian wild marjoram (Origanum vulgare L.) populations. In: 44th International symposium on essential oils. Abstracts, p 126 
Dani KGS, Jamie IM, Prentice IC, Atwell BJ (2015) Species-specific photorespiratory rate, drought tolerance and isoprene emission rate in plants. Plant Signal Behav 10(3):e990830-1-e990830-3. https://doi.org/10.4161/15592324.2014.990830

Debnath M, Pandey M, Bisen PS (2011) An omics approach to understand the plant abiotic stress. OMICS J Integr Biol. https ://doi.org/10.1089/omi.2010.0146

Delfine S, Loreto F, Pinelli P, Tognetti R, Alvino A (2005) Isoprenoids content and photosynthetic limitations in rosemary and spearmint plants under water stress. Agric Ecosyst Environ 106:243-252

Dement WA, Tyson BJ, Moone HA (1975) Mechanism of monoterpene volatilization of Salvia mellifera. Phytochemistry 14:2555-2557

Dietrich LEP, Teal TK, Price-Whelan AK, Newman DK (2008) Redoxactive antibiotics control gene expression and community behavior in divergent bacteria. Science 321(5893):1203-1206. https:// doi.org/10.1126/science.1160619

Dudareva N, Pichersky E, Gershenzon J (2004) Biochemistry of plant volatiles. Plant Physiol 135:1893-1902. https://doi.org/10.1104/ pp.104.049981

Dudareva N, Andersson S, Orlova I, Gatto N, Reichelt M, Rhodes D, Boland W, Gershenzon J (2005) The nonmevalonate pathway supports both monoterpene and sesquiterpene formation in snapdragon flowers. Proc Natl Acad Sci USA 102:933-938

Foyer Ch, Descourvieres P, Kunert KJ (1994) Photo oxidative stress in plants. Plant Physiol 92:696-717

Furr JR, Reeve JO (1945) Range of Soil-Moisture Percentages through which some plants undergo permanent wilting in some soils from semiarid irrigated areas. J Agric Res 71(4):149-170

Griesser M, Weingart G, Schoedl-Hummel K, Neumann N, Becker M, Varmuza K, Liebner F, Schumacher R, Forneck A (2015) Severe drought stress is affecting primary metabolites, polyphenols and volatile metabolites in grapevine leaves (Vitis vinifera cv. Pinot noir). Plant Physiol Biochem 88:17-26

Heinig U, Gutensohn M, Dudareva N, Aharoni A (2013) The challenges of cellular compartmentalization in plant metabolic engineering. Curr Opin Biotechnol 24(2):239-246. https://doi. org/10.1016/j.copbio.2012.11.006

Hussein AH, Said-Al A, Sabra AS, Alataway A, Astatkie T, Mahmoud AA, Bloem E (2019) Biomass production and essential oil composition of Thymus vulgaris in response to water stress and harvest time. J Essent Oil Res 31(1):63-68. https://doi.org/10.1080/10412 905.2018.1518794

Iijima Y, Davidovich-Rikanati R, Fridman E, Gang DR, Bar E, Lewinsohn E, Pichersky E (2004) The biochemical and molecular basis for the divergent patterns in the biosynthesis of terpenes and phenylpropenes in the peltate glands of three cultivars of basil. Plant Physiol 136:3724-3736

ISO 9235:2013/COR (2014) 1:2014

Kesselmeier J, Staudt M (1999) Biogenic volatile organic compounds (VOC): an overview on emission, physiology and ecology. J Atmos Chem 33:23-88

Khalid KhA (2006) Influence of water stress on growth, essential oil, and chemical composition of herbs (Ocimum sp.). Int Agrophys 20:289-296

Khalil SE, El-Noemani AA (2015) Effect of bio-fertilizers on growth, yield, water relations, photosynthetic pigments and carbohydrates contents of Origanum vulgare L. plants grown under water stress conditions. Am Euras J Sustain Agric 9(4):60-73

Kleinwächter M, Selmar D (2015) New insights explain that drought stress enhances the quality of spice and medicinal plants: potential applications. Agron Sustain Dev 35:121-131. https://doi. org/10.1007/s13593-014-0260-3

Kleinwächter M, Paulsen J, Bloem E, Schnug E, Selmar D (2015) Moderate drought and signal transducer induced biosynthesis of relevant secondary metabolites in thyme (Thymus vulgaris), greater celandine (Chelidonium majus) and parsley (Petroselinum crispum). Ind Crops Prod 64:158-166

Kreuzwieser J, Graus M, Wisthaler A, Hansel A, Rennenberg H, Schnitzler J-P (2002) Xylem-transported glucose as an additional carbon source for leaf isoprene formation in Quercus robur. New Phytol 156:171-178

Kulak M, Ozkan A, Bindak R (2019) A bibliometric analysis of the essential oil-bearing plants exposed to the water stress: how long way we have come and how much further? Sci Hortic 246:418-436

Laribi B, Bettaieb I, Kouki K, Sahli A, Mougou A, Marzouk B (2009) Water deficit effects on caraway (Carum carvi L.) growth, essential oil and fatty acid composition. Ind Crops Prod 30(3):372-379

Lewitt J (1980) Responses of plants to environmental stresses. Volume II. Water, radiation, salt and other stresses. Academic Press, New York, pp 25-27

Lichtenthaler HK (1996) Vegetation stress: an introduction to the stress concept in plants. J Plant Physiol 148:4-14

Lichtenthaler HK (1999) The 1-deoxy-D-xylulose-5-phosphate pathway of isoprenoid biosynthesis in plants. Annu Rev Plant Physiol Plant Mol Biol 50:47-65

Llusià J, Peñuelas J (1998) Changes in terpene content and emission in potted Mediterranean woody plants under severe drought. Can J Bot 76:1366-1373

Loreto F, Ciccioli P, Cecinato A, Brancaleoni E, Frattoni M, Tricoli D (1996) Influence of environmental factors and air composition on the emission of a-pinene from Quercus ilex leaves. Plant Physiol 110:267-275

Mandoulakani BA, Eyvazpour E, Ghadimzadeh M (2017) The effect of drought stress on the expression of key genes involved in the biosynthesis of phenylpropanoids and essential oil components in basil (Ocimum basilicum L.). Phytochemistry 139:1-7

McCaskill D, Croteau R (1995) Monoterpene and sesquiterpene biosynthesis in glandular trichomes of peppermint (Mentha $\mathrm{x}$ piperita) rely exclusively on plastid-derived isopentenyl diphosphate. Planta 197:49-56

McKiernan AB, Hovenden MJ, Brodribb TJ, Potts BM, Davies NW, O'Reilly-Wapstra JM (2014) Effect of limited water availability on foliar plant secondary metabolites of two Eucalyptus species. Environ Exp Bot 105:55-64

Mohasseli V, Sadeghi S (2019) Exogenously applied sodium nitroprusside improves physiological attributes and essential oil yield of two drought susceptible and resistant specie of Thymus under reduced irrigation. Ind Crops Prod 130:130-136

Moradi P, Ford-lloyd B, Pritchard J (2017) Metabolomic approach reveals the biochemical mechanisms underlying drought stress tolerance in thyme. Anal Biochem 527:49-62. https://doi. org/10.1016/j.ab.2017.02.006

Morshedloo MR, Craker LE, Salami A, Nazeri V, Sang H, Maggi F (2017) Effect of prolonged water stress on essential oil content, compositions and gene expression patterns of mono- and sesquiterpene synthesis in two oregano (Origanum vulgare L.) subspecies. Plant Physiol Biochem 111:119e128. https://doi. org/10.1016/j.plaphy.2016.11.023

Munné-Bosch S, Alegre L (1999) Role of dew on the recovery of waterstressed Melissa officinalis plants. J Plant Physiol 154:759-766

Nakabayashi R, Yonekura-Sakakibara, Urano KK, Suzuki M, Yamada Y, Nishizawa T, Matsuda F, Kojima M, Sakakibara H, Shinozaki K, Michael AJ, Tohge T, Yamazaki M, Saito K (2014) Enhancement of oxidative and drought tolerance in Arabidopsis by overaccumulation of antioxidant flavonoids. Plant J 77:367-379. https:// doi.org/10.1111/tpj.12388

Németh-Zámbori É, Szabó K, Pluhár Zs, Radácsi P, Inotai K (2016) Changes in biomass and essential oil profile of four Lamiaceae species due to different soil water levels. J Essent Oil Res 28(5):391-399. https://doi.org/10.1080/10412905.2016.1176606 
Németh-Zámbori É, Szabó K, Rajhárt P, Inotai K, Seidler-Lozykowska K, Radácsi P (2017) Variability of phenolic compounds of four Lamiaceae species in consequence of different water supply. Acta Scientiarum Polonorum Hortorum Cultus 16(4):13-24

Nowak M, Kleinwächter M, Manderscheid R, Weigel HJ, Selmar D (2010) Drought stress increases the accumulation of monoterpenes in sage (Salvia officinalis), an effect that is compensated by elevated carbon dioxide concentration. J Appl Bot Food Qual 83(2):133-136

Owen SM, Peñuelas J (2005) Opportunistic emissions of volatile isoprenoids. Trends Plant Sci 10(9):420-426

Paulsen J, Selmar D (2016) Case study: the difficulty of correct reference values when evaluating the effects of drought stress: a case study with Thymus vulgaris. J Appl Bot Food Qual 89:287-289

Petropoulos SA, Daferera D, Polissiou MG, Passam HC (2008) The effect of water deficit stress on the growth, yield and composition of essential oils of parsley. Sci Hortic 115(4):393-397

Pott DM, Osorio S, Vallarino JG (2019) From central to specialized metabolism: an overview of some secondary compounds derived from the primary metabolism for their role in conferring nutritional and organoleptic characteristics to fruit. Front Plant Sci 10:835. https://doi.org/10.3389/fpls.2019.00835

Price-Whelan A, Dietrich LEP, Newman DK (2007) Pyocyanin alters redox homeostasis and carbon flux through central metabolic pathways in Pseudomonas aeruginosa PA14. J Bacteriol 189(17):6372-6381. https://doi.org/10.1128/JB.00505-07

Radácsi P, Inotai K, Sárosi Sz, Németh É (2016) Effect of soil water content on the physiological parameters, production and active substances of summer savory (Satureja hortensis L.). Acta Scientiarum Polonorum Hortorum Cultus 15(2):3-12

Raghavendra AS, Padmasree K (2003) Beneficial interactions of mitochondrial metabolism with photosynthetic carbon assimilation. Trends Plant Sci 8(11):546-553

Rodríguez-Calcerrada J, Buatois B, Chiche E, Shahin O, Staudt M (2013) Leaf isoprene emission declines in Quercus pubescens seedlings experiencing drought - any implication of soluble sugars and mitochondrial respiration? Environ Exp Bot 85:36-42

Rosenkranz M, Schnitzler JP (2016) Plant volatiles. eLS. Wiley, Chichester. https://doi.org/10.1002/9780470015902.a0000910.pub3

Saeedfar S, Negahban M, Soorestani MM (2015) the effect of drought stress on the essential oil content and some of the biochemical characteristics of Anise Hyssop (Agastache foeniculum [Pursh] Kuntze). Eur J Mol Biotechnol 8(2):103-114. https://doi. org/10.13187/ejmb.2015.8.103

Said-Al Ahl HAH, Abdou MAA (2009) Impact of water stress and phosphorus fertilizer on fresh herb and essential oil content of dragonhead. Inst Agrophys 23:403-407

Said-Al Ahl HAH, Omer EA, Naguib NY (2009) Effect of water stress and nitrogen fertilizer on herb and essential oil of oregano. Inst Agrophys 23:269-275

Selmar D, Kleinwächter M (2013a) Influencing the product quality by deliberately applying drought stress during the cultivation of medicinal plants. Ind Crops Prod 42:558-566

Selmar D, Kleinwächter M (2013b) Stress enhances the synthesis of secondary plant products: the impact of stress-related over-reduction on the accumulation of natural products. Plant Cell Physiol 54(6):817-826

Shairat A, Karimzadeh G, Assareh MH, Hadian J (2018) Metabolite profiling and molecular responses in a drought-tolerant savory, Satureja rechingeri exposed to water deficit. 3 Biotech 8:477. https://doi.org/10.1007/s13205-018-1491-9

Simon JE, Reiss-Bubenheim D, Joly RJ, Charles DJ (1992) Water stress-induced alterations in essential oil content and composition of Sweet Basil. J Essent Oil Res 4:71-75

Šimpraga M, Verbeeck H, Demarcke M, Joó É, Pokorska O, Amelynck C, Schoon N, Dewulf J, Van Langenhove H, Heinesch B, Aubinet
M, Laffineur Q, Müller J-F, Steppe K (2011) Clear link between drought stress, photosynthesis and biogenic volatile organic compounds in Fagus sylvatica L. Atmos Environ 45(30):5254-5259

Staudt M, Seufert G (1995) Light-dependent emission of monoterpenes by Holm Oak (Quercus ilex L.). Naturwissenschaften 82:89-92

Szabó K, Radácsi P, Rajhárt P, Ladányi M, Németh É (2017) Stressinduced changes of growth, yield and bioactive compounds in lemon balm cultivars. Plant Physiol Biochem 119:170-177

Tardieu F (1996) Drought perception by plants. Do cells of droughted plants experience water stress? Plant Growth Regul 20:93-104

Tholl D, Boland W, Hansel A, Loreto F, Röse USR, Schnitzler J (2006) Practical approaches to plant volatile analysis. Plant J 45:540-560. https://doi.org/10.1111/j.1365-313X.2005.02612.X

Tissier A, Morgan JA, Dudareva N (2017) Plant volatiles: going 'In' but not 'Out' of Trichome Cavities. Trends Plant Sci 22(11):930-938

Turtola S, Manninen A, Rikala R, Kailunainen P (2003) Drought stress alters the concentration of wood terpenoids in scots pine and Norway spruce seedlings. J Chem Ecol 29(9):1981-1994

Vranová E, Coman D, Gruissem W (2013) Network analysis of the MVA and MEP pathways for isoprenoid synthesis. Annu Rev Plant Biol 64:665-700. https://doi.org/10.1146/annurev-arpla nt-050312-120116

Wang W, Vinocur B, Altman A (2003) Plant responses to drought, salinity and extreme temperatures: towards genetic engineering for stress tolerance. Planta 218:1-14. https://doi.org/10.1007/s0042 5-003-1105-5

Werker E (1993) Function of essential oil-secreting glandular hairs in aromatic plans of Lamiacea-a review. Flavour Fragrance J $8(5): 249-255$

Witcombe JR, Hollington PA, Howarth CJ, Reader S, Steele KA (2016) Breeding for abiotic stresses for sustainable agriculture. Philos Trans R Soc 363:703-716

Wu C, Pullinen I, Andres S, Carriero G, Fares S, Goldbach H, Hacker L, Kasal T, Kiendler-Scharr A, Kleist E, Paoletti E, Wahner A, Wildt J, Mentel ThF (2015) Impacts of soil moisture on de novo monoterpene emissions from European beech, Holm oak, Scots pine, and Norway spruce. Biogeosciences 12:177-191. https://doi. org/10.5194/bg-12-177-2015

Yadav RK, Sangwan RS, Sabir F, Srivastava AK, Sangwan NS (2014) Effect of prolonged water stress on specialized secondary metabolites, peltate glandular trichomes, and pathway gene expression in Artemisia annua L. Plant Physiol Biochem 74:70-83

Yuan Y, Yunyun L, Chong W, Shunqin C, Zhouyong W, Zhaochum Y, Shuangshuang Q, Luqi H (2012) Water deficit affected flavonoid accumulation by regulating hormone metabolism in Scutellaria baicalensis Georgi roots. PLoS One 7(10):e42946

Yuhang C, Qiaosheng G, Li L, Li L, Zaibiao Z (2011) Influence of fertilization and drought stress on the growth and production of secondary metabolites in Prunella vulgaris L. J Med Plant Res 5(9):1749-1755

Zámboriné Németh É, Radácsi P, Gosztola B, Rajhárt P, Szabó K (2017) Influence of water supply and fluctuations on yield and quality of lemon balm (Melissa officinalis L.). Aust J Crop Sci 11(12):1539-1546. https://doi.org/10.21475/ajcs.17.11.12.pne665

Zhang J, Gao F, Jia H, Hu J, Feng Z (2019) Molecular response of poplar to single and combined ozone and drought. Sci Total Environ 655:1364-1375

Publisher's Note Springer Nature remains neutral with regard to jurisdictional claims in published maps and institutional affiliations. 